\title{
Study of the biogas potential generated from residue: peanut shells
} Estudo do potencial de geração de biogás a partir de resíduos: casca de amendoim

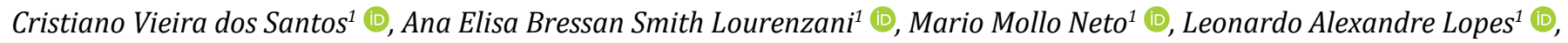 \\ Paulo Sérgio Barbosa dos Santos ${ }^{1}$ (D)
}

\begin{abstract}
A B S T RAC T
The increase in agricultural production generates a large volume of waste, which may lead to concerns about its proper destination. The main economic activity in Herculândia City, Western region of São Paulo State, Brazil, is the production and processing of peanuts. In this process, a large volume of peanut shells is generated. Following the current movement of using waste for energy purposes, in compliance with what was established by the Sustainable Development Goals (SDGs), this work aimed to carry out a study on the biogas potential generated from peanut shells. To this end, a low-cost biodigester prototype was built, which, over a period of 108 days, produced biogas and biofertilizer. The results showed that there was production of biogas from peanut waste; however, the volume produced did not provide savings in electricity costs when compared to the production of biogas from animal waste. Nevertheless, the work demonstrated the importance of providing solutions to the disposal of peanut shells, effectively mitigating future environmental problems, and serving as an alternative for generating sustainable and low-cost energy, especially for small producers.
\end{abstract}

Keywords: biogas; peanut shells; electricity; waste.

\begin{abstract}
RE S U M 0
O aumento da produção agrícola gera um grande volume de resíduos, podendo levar a preocupações quanto à sua adequada destinação. O município de Herculândia, no oeste do estado de São Paulo, tem como principal atividade econômica a produção e processamento de amendoim. Nesse processo é gerado um grande volume de cascas. Seguindo a tendência da utilização de resíduos para fins energéticos, atendendo ao estabelecido pelos Objetivos de Desenvolvimento Sustentável (ODS), este trabalho teve como objetivo realizar um estudo sobre o potencial de geração de biogás a partir da casca do amendoim. Para tal, foi construído um protótipo de biodigestor de baixo custo que, em um período de 108 dias, produziu biogás e biofertilizante. Os resultados demostraram que houve produção de biogás a partir do resíduo; entretanto, o volume produzido não propiciou economia no custo de energia elétrica, quando comparado à produção de biogás oriunda de dejetos animais. No entanto, o trabalho demonstrou a importância de prover soluções ao descarte de resíduos da casca de amendoim, efetivamente mitigando futuros problemas ambientais e servindo como alternativa geradora de energia sustentável e de baixo custo, principalmente para pequenos produtores.
\end{abstract}

Palavras-chave: biogás; casca de amendoim; energia elétrica; resíduo.

\footnotetext{
${ }^{1}$ Universidade Estadual Paulista "Júlio de Mesquita Filho" - Tupã (SP), Brazil.

Corresponding address: Cristiano Vieira dos Santos - Rua Euclides da Cunha, 879 - Centro - CEP 17650-000 -Herculândia (SP), Brazil E-mail: cristianoambiental.eng@gmail.com
}

Conflicts of interest: the authors declare there is no conflict of interests.

Funding: none.

Received on: 04/23/2020. Accepted on: 09/16/2020.

https://doi.org/10.5327/Z21769478765 


\section{Introduction}

Agricultural activities, as well as the processing of agricultural products, have been causing several environmental problems related to the waste generated during this process (Pelissari et al., 2010). The concern involves slurry, which is a result of decomposition of organic residues that presents a high contaminating factor. Slurry has the following main characteristics: dark color, unpleasant odor, and high toxicity (Miyagawa et al., 2016), with potential risk to contaminate the subsoil and groundwater with heavy metals and other substances highly harmful to human health (Milhomem Filho et al., 2016).

The use of renewable energy to meet the demands of the country's energy matrix is urgent and necessary, since the inputs used in agricultural production are finite, and the practice of monoculture exhausts the soil. In addition, agricultural residues and by-products, in some cases, may have a polluting potential, damaging the environment (Pelissari et al., 2010). Moreover, the use of renewable energy is one of the most discussed and globally relevant issues, part of the 2030 Agenda for Sustainable Development, proposed by the United Nations (UN), seeking to eradicate poverty, protect the planet, and ensure that people achieve peace and prosperity (UN, 2015). The restricted space and the increasing need to meet the demand for clean energy production, water, and food indicate that some paradigms need to be overcome, aiming to meet energy and environmental challenges of the global community (Brasil, 2018).

In line with the concept of sustainability, the Brazilian National Policy on Solid Waste (PNRS, as its acronym in Portuguese) was established in 2010, regulated by Law 12.305 / 2010. The PNRS is an important instrument with the purpose of regulating the management of solid waste, thus leading the country to follow paths that aim at improving the quality of life and environmental preservation (Brasil, 2010).

Industries in general, including those inserted in agricultural activities, are responsible for returning the residues to the productive centers and giving them the correct destination (Azevedo, 2014). An example of proper destination is in the sugar and alcohol sector, that carries out the recycling of straw and sugarcane bagasse, practices which contribute to sustainable development (Verri et al., 2017). According to Barbieri et al. (2010), the great challenge is to promote organizations that innovate efficiently in all three dimensions of sustainability: economic, social, and environmental.

For Polachini et al. (2016), one of the biggest environmental concerns is related to the intense use of fossil fuel. For that reason, new technologies and renewable sources for producing energy from agro-industrial residue are relevant due to its low-cost and availability, mainly in countries with agricultural potential, like Brazil. The increasing generation of residue is a major challenge, especially for developing countries that still face difficulties to correctly treat its residues (Feil et al., 2015). This problem happens because, in addition to leachate, another aspect must be considered about the disposal of organic residue when it does not receive the proper treatment: the increase in the emission of greenhouse gases (GHG). Zanoni et al. (2015) point out that the decomposition of materials produces mainly methane $\left(\mathrm{CH}_{4}\right)$. According to Chizzotti et al. (2012), this gas can pollute 23 to 25 times more than carbon dioxide $\left(\mathrm{CO}_{2}\right)$, requiring from nine to 15 years to be eliminated.

Even when considering specific questions regarding the aggravations caused by organic residue from agricultural production, the economic importance of agribusiness in Brazil should not be ignored. Agribusiness accounted for $21.4 \%$ of the Brazilian Gross Domestic Product (GDP) in 2019 (CEPEA/ESALQ; CNA, 2020), in addition to being responsible for producing staples and commodities for domestic and foreign markets. This leads to a reflection on the potential of such residue from countless activities present for its reuse.

Correa et al. (2019) point out that one use for the residues consists in transforming biomass into energy sources, contributing to supply the demands of the country's energy matrix, which seeks to increase the contribution of renewable energy.

Aziz and Hanafiah (2020), in their study on the production of biogas from solid organic residue in Malaysia, emphasize that this conversion appears as a promising technology, being able to achieve sustainable development through clean energy and sustainable consumption, in line with the SDGs (UN, 2015).

Bilotta and Ross (2016) point out that the agribusiness, in general, is a major source of residue, such as vegetables from the harvest, besides the processing residues, shells, straw, bark, and seeds, which have properties in their composition that allow them to be reused to generate energy. However, in Brazil, less than half of these materials are reused for this purpose, with more than 200 million tons of agro-industrial residue being discarded without reuse (Almeida, 2012).

The processing of peanuts generates a large volume of shells. Seeking to better treat residue associated with the use of new technologies, previous attempts were made to use peanut shells for producing bioethanol through the decomposition of hemicellulose, which passes in the fermentation process, ethanol production and, later, distillation, thus converting agricultural residue into biofuels (Polachini et al., 2016).

Slorach et al. (2019) emphasize the importance of studying anaerobic digestion in environmental sustainability. For this, rethinking the current development model, adopting sustainable practices, and visualizing new means of production is needed. Hence, the economic, social, and environmental dimensions must be considered, looking for new technologies associated with the production of renewable energy that causes less impact on the environment (Awasthi et al., 2018).

Based on this, the biodigester emerges as a tool capable of transforming residue into renewable energy (Oliveira et al., 2018). Biasi et al. (2018) mention that the anaerobic digestion carried out by biodigesters is a strategy with great potential for treating agro-industrial residue, since they do not require large areas for their construction and allow the reduction of residue that have a predisposition to pollute the environment. Thus, the energy 
sector, for being capable of providing energy and biofertilizers, should consider this (Campos et al., 2011; Kunz et al., 2019).

In this sense, this work sought to study the potential of biogas generation from peanut shells. Such residue is generated in large amounts in the processing of peanuts and can be applied in several ways (Zhao et al., 2012).

The locus of analysis was the Tupã region. Located in the Midwest of São Paulo State, it is considered one of the main producing regions for peanut crop in Brazil. The great relevance of this production is evident both in economic and social aspects, since it generates a large number of jobs in the agro-industrial system.

Herculândia City, located in the Tupã region, is inserted in this pole producer; and peanut crop is the main source of its economy, from cultivation to seed processing. According to data from the Brazilian Institute of Geography and Statistics (Instituto Brasileiro de Geografia e Estatística - IBGE, 2017), 29 farms that produce peanut are located within the perimeter of Herculândia, ranging from large to small farms. In 2015, the city stood out in the ranking of planted and harvested areas in São Paulo State, assuming the first position; in terms of volume produced, it ranked third, accounting for an amount of 17.8 thousand tons of peanuts (IBGE, 2017).

According to Araújo et al. (2014), 30\% of all agricultural peanut production correspond to shells. Estimates say that $1,350 \mathrm{~kg} / \mathrm{ha}$ shells are generated. Such residue, due to its large volume and difficulty of storage, is considered difficult to use for other purposes. Lora and Andrade (2009) add that, if agricultural residue were destined for energy transformation, it could contribute significantly to sustainability and to the energy matrix of the country.

\section{Materials and Methods}

For research development, three 120-liter containers with removable cover and sealing system were used. The cylindrical containers are of opaque blue color to prevent the incidence of sunlight on the material stored inside. These cylinders simulate the conditions of the Indian and Canadian biodigesters (Bezerra et al., 2014).

To allow the anaerobic fermentation process, the containers were interconnected. In addition to the 120-liter containers, 50-liter container with removable cover, PVC pipes, connections, glues, sealing materials, purifying filter for sulphidic acid $\left(\mathrm{H}_{2} \mathrm{~S}\right)$, carbon dioxide $\left(\mathrm{CO}_{2}\right)$ and humidity, thermometer, and container for biogas storage were used, as described in Table 1.

After the identification of the materials necessary for the preparation of the biodigester, construction began as shown in Figure 1.

Figure 2 shows the prototype of the biodigester that was built at Universidade Estadual de São Paulo "Júlio de Mesquita Filho" (UNESP), Campus of Tupã.

The prototype was installed on a farm located in Herculândia City, São Paulo State. To speed up the biodigestion process, the prototype was buried so that the temperature was kept between 25 and $35^{\circ} \mathrm{C}$, since the temperature influences the decomposition of organic matter and the amount of methane $\left(\mathrm{CH}_{4}\right)$ present in the biogas (Mota et al., 2019).

After installing the biodigester, peanut shells were crushed with a forage crusher with a gasoline engine, power of $5.5 \mathrm{HP}$, and a 3 $\mathrm{mm}$ sieve. Crushing is an extremely important step in biodigestion. Galbiatti et al. (2011) point out that the difference between the use of whole residues and crushed ones can reach an increase of $53 \%$ of the methane gas present in the biogas produced using peanut shells and poultry litter.

Then, the barrels were filled with a ratio of 1 liter of crushed shell to 3 liters of water. The mixing process was carried out prior to the barrel feeding. All the material was stored inside the feeding container; after mixing the materials, the valve was opened, and all the compost was sent to the first container.

In this way, the volume of 72 liters of crushed peanut shells $(11.4 \mathrm{~kg})$ was mixed with 216 liters of water. After the feeding process, all valves were closed to start the anaerobic fermentation process inside the biodigester.

After 45 days of feeding, considering that the minimum period of biogas production is between 45 and 60 days (Galbiatti et al., 2011), three filters were installed, with the objective of removing hydrogen

Table 1 - Main materials used to build the prototype

\begin{tabular}{|c|c|c|}
\hline Material & Dimension & $\begin{array}{c}\text { Quantity } \\
\text { (Unit/meters) }\end{array}$ \\
\hline Drum (plastic drum barrel) & 120 liters & 3 \\
\hline Drum (plastic drum barrel) & 50 liters & 2 \\
\hline Flange & $1 / 2 ”$ & 1 \\
\hline Flanges & $2 ”$ & 9 \\
\hline $45^{\circ}$ Curves & $1 / 2 "$ & 1 \\
\hline $45^{\circ}$ Curves & $2 ”$ & 8 \\
\hline PVC Pipe & $2 ”$ & 5 \\
\hline Valve & $1 / 2 "$ & 1 \\
\hline Valve & $2 ”$ & 2 \\
\hline $\begin{array}{l}\text { Quick Connect / } \\
\text { Quick Connect Connector }\end{array}$ & $1 / 2 "$ & $10 / 10$ \\
\hline Thread Seal & Medium & 1 \\
\hline PVC Lid & $4 ”$ & 6 \\
\hline PVC Pipe & $4 ”$ & 2 \\
\hline T PVC & $1 / 2 "$ & 2 \\
\hline Transparent Flexible Hose & $1 / 2 "$ & 2 \\
\hline Pivot & $1 / 2 "$ & 10 \\
\hline Clamp & $1 / 2 "$ & 10 \\
\hline Tap & $1 / 2 "$ & 1 \\
\hline
\end{tabular}


sulphide, carbon dioxide, and the humidity present in the gas, as illustrated in Figure 3.

In the first filter, a steel wool roll was added, with the purpose of removing sulfate compounds, such as hydrogen sulfide, which impairs the storage of the gas and its burning (Brancoli, 2014). Seeking a functional and accessible technology, the steel wool roll was used due to its low-cost acquisition. When the biogas encounters the various layers, the $\mathrm{H}_{2} \mathrm{~S}$ reacts with the iron oxide and iron hydroxides, forming the iron sulfides that are fixed on the material, causing its oxidation (Ryckebosch et al., 2011).

In the second filter, a mixture of water and chlorine (bleach) with an approximate volume of 1.5 liters was added. The second filter has different characteristics from the others. The biogas inlet and outlet are located at the top, causing the produced gas to pass through the mixture and go to the next filter. To avoid degradation of the chlorine present in the mixture, after installing the filter, the replacement of the compound occurred every 10 days. The main function of the mixture is removing carbon dioxide produced from anaerobic biodigestion (Brancoli, 2014).

In the third filter, silica gel was placed to remove the moisture present in the biogas and increase the calorific value of the compound (Baldacin and Pinto, 2015). To assist in the removal process, approximately $1 \mathrm{~kg}$ of material was introduced into the container. In order to identify whether the removal of moisture from the gas was taking place, changes in the pigmentation of the silica gel were observed. After that, thread sealant was used in the caps, and silicone in the inlets and outlets of the filters, seeking to reduce the risk of leakage of the produced biogas (Table 1).

To close the cycle, an air chamber was installed in the last filter to store the generated biogas. Two gas valves were used, the first on the outlet hose of the last filter, the second on the nozzle of the chamber (Table 2).

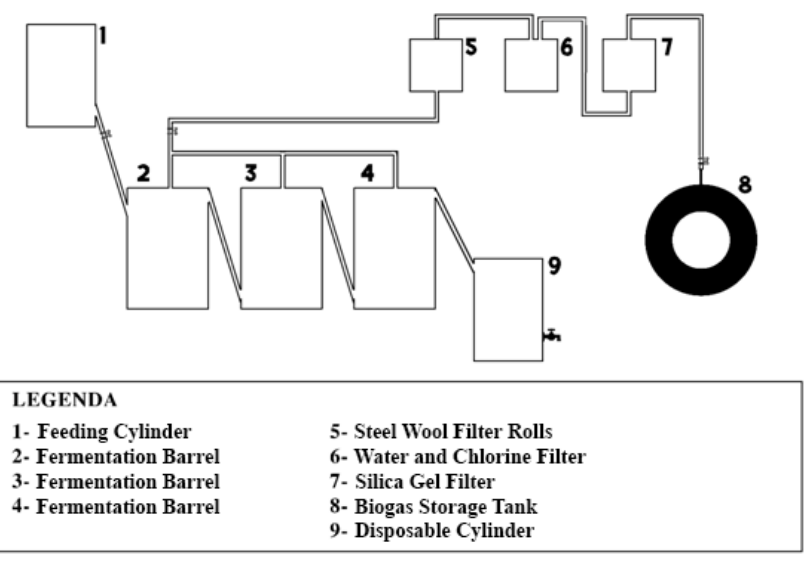

\section{Figure 1 - Sketch of the biodigester prototype}

1: feeding cylinder; 2 : fermentation barrel; 3 : fermentation barrel; 4 : fermentation barrel; 5: steel wool filter rolls; 6: water and chlorine filter; 7: silica gel filter; 8: biogas storage tank; 9: disposable cylinder.

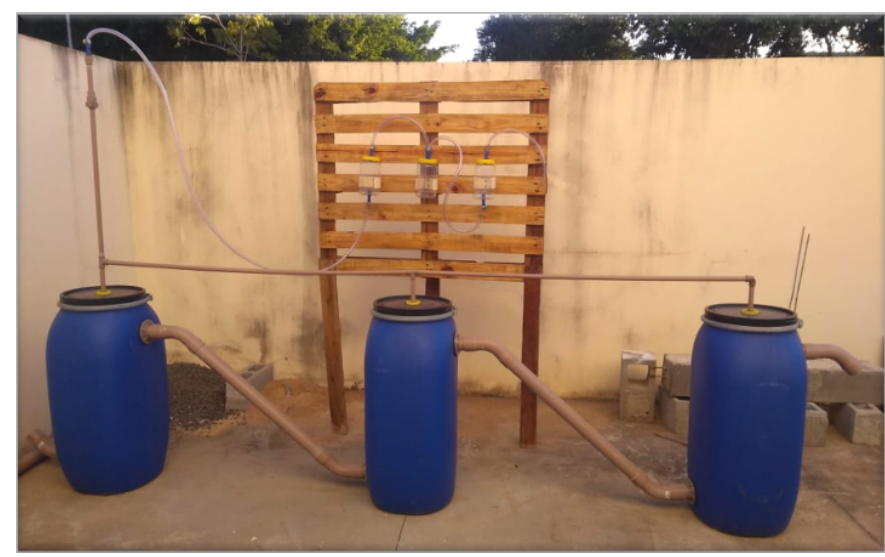

Figure 2 - Biodigester prototype
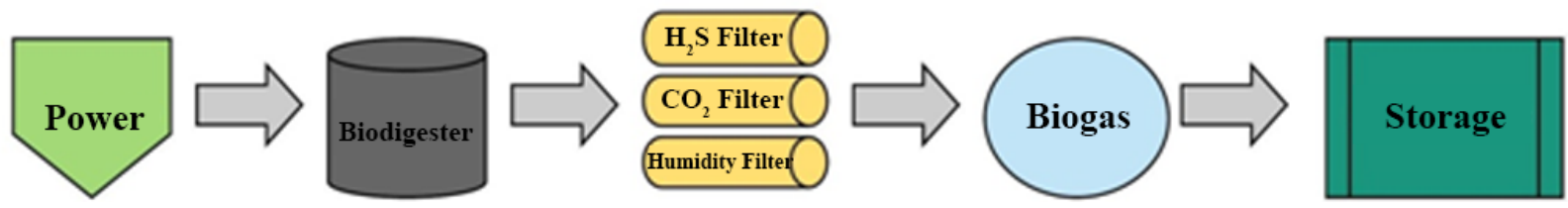

Figure 3 - Flowchart of biogas production

Source: adapted from Bonfim et al. (2019).

Table 2 - Summary of the filters used in the biogas purification

\begin{tabular}{|l|l|r|}
\hline Filter & Utilized Material & Description \\
\hline Filter 1 & Steel Wool & $\begin{array}{r}\text { Steel wool filter roll. Objective: to remove sulfate compounds, such as hydrogen sulfide, } \\
\text { which impairs the storage of the gas and its burning (Brancoli, 2014) }\end{array}$ \\
\hline Filter 2 & Water and Chlorine & $\begin{array}{r}\text { Approximately 1.5-liter mixture. Objective: to remove carbon dioxide produced from } \\
\text { anaerobic digestion (Brancoli, 2014). }\end{array}$ \\
\hline Filter 3 & Silica Gel & $\begin{array}{r}\text { Packaged Silica gel. Objective: to remove the moisture present in the biogas, thus increasing } \\
\text { the calorific value of the compound (Baldacin and Pinto, 2015) }\end{array}$
\end{tabular}


Table 3 - Biogas energy equivalence

\begin{tabular}{|c|c|}
\hline Fuel & $\mathbf{1 ~}^{\mathbf{3}}$ Biogas Equivalence \\
\hline Gasoline & $0.6 \mathrm{~L}$ \\
\hline Kerosene & $0.57 \mathrm{~L}$ \\
\hline Diesel & $0.55 \mathrm{~L}$ \\
\hline Liquefied Petroleum Gas & $0.45 \mathrm{~kg}$ \\
\hline Ethanol & $0.79 \mathrm{~L}$ \\
\hline Firewood & $1.536 \mathrm{~kg}$ \\
\hline Electric Power & $1.428 \mathrm{kWh}$ \\
\hline
\end{tabular}

Source: adapted from Almeida (2016).

For estimating the savings in electricity consumption generated by biogas production, energy equivalence parameters were used, according to Masson et al. (2015), who relate the equivalence of 1 $\mathrm{m}^{3}$ of biogas produced with the other types of fuels, as shown in Table 3.

\section{Results}

During the entire process of biodigestion of the residue, tests on the barrels and connections were carried out to identify possible leaks. The first indication of the production of biogas occurred 72 days after the feeding process, after opening the regulator that connected the buried system to the filters. At that moment, the appearance of bubbles inside the second filter, composed of chlorine and water, was seen.

Subsequently, the regulators were closed to increase the pressure inside the biodigester. For biogas storage, an air chamber with an approximate height of $0.22 \mathrm{~m}$, external radius of $0.40 \mathrm{~m}$, and internal radius of $0.18 \mathrm{~m}$ was used. Equation 1 was adopted to identify the filling volume of the chamber:

$$
V=\pi \cdot h\left(R^{2}-r^{2}\right)
$$

Where:

$\mathrm{V}=$ Volume;

$\pi=\mathrm{Pi}$

$\mathrm{h}=$ Height;

$\mathrm{R}=$ External radius;

$\mathrm{r}=$ Internal radius.

Likewise, chamber volume was identified according to Equation 2.

$$
V=3,14.0,22\left(0,4^{2}-0,18^{2}\right)=0,088 \mathrm{~m}^{3}
$$

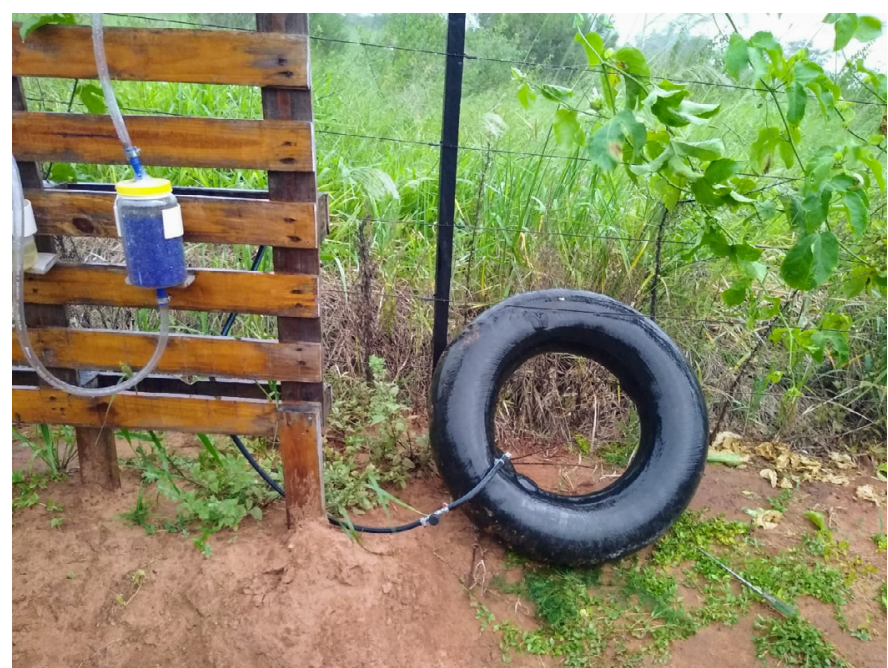

Figure 4 - Air chamber filled with biogas

Table 4 - Filling the packaging chamber

\begin{tabular}{|c|c|}
\hline Number of days & Accumulated $\mathbf{m}^{3}$ \\
\hline 72 & 0.08 \\
\hline 94 & 0.16 \\
\hline 101 & 0.04 \\
\hline 108 & No production \\
\hline Total & 0.2 \\
\hline
\end{tabular}

After knowing the volume of the biogas storage container, regulators were opened, observing the movement of the liquid in the second filter. In sequence, the air chamber used to store the produced biogas began to inflate. Due to the low pressure of the system and the low resistance of the filters, the regulators were closed when filling the volume of a chamber, so that the gas would not return and break the chambers. Lastly, the chamber was emptied.

In the following week, steel wool roll of the first filter was oxidized, and so, it was replaced. The second opening of the regulators took place 94 days after the feeding process, following the same method as before. After 101 days, when opening the regulators, a decrease in biogas production was detected. When analyzing the air chamber, a volume corresponding to only half of its capacity was observed $\left(0.04 \mathrm{~m}^{3}\right)$. After that, the regulators were closed, and the chamber was emptied. Figure 4 shows the first biogas production.

Table 4 shows the number of days on which gas production was verified, making up an amount of $0.2 \mathrm{~m}^{3}$ of gas generated from the mixture. 
Following the conclusion of the biodigestion process, there was no biogas production after 115 days. On this date, the unloading barrel was opened and the biofertilizer was accessed to identify its properties.

At the end of the process, a volume of 22 liters of biofertilizer was produced with the following characteristics: potential hydrogen $(\mathrm{pH})$ of 6.4 and temperature of $21^{\circ} \mathrm{C}$. According to Santos (1991), the $\mathrm{pH}$ of the biofertilizer can vary from 7.0 to 8.0 or be lower when fermentation is incomplete.

In the sensorial analysis, the presence of odor in the biofertilizer was observed. However, it did not present a putrefaction smell. As to its color, it presented light brown pigmentation. The quality of the biofertilizer is verified by means of color and odor, which is of low quality when it presents a putrefying odor and the foam that forms on the surface tends to be black (Gonçalves et al., 2009; Oliveira Filho et al., 2020). In such cases, it is suggested that the biofertilizer be discarded.

Table 5 presents a summary of the results obtained regarding gas production parameters.

Peanut shells stowed in the digester presented a methanogenic potential corresponding to $0.2 \mathrm{~m}^{3}$ produced from $11.4 \mathrm{~kg}$ of residue, taking into account the 108-day conditioning period and external circumstances (rain and temperature).

The last evaluation of the biogas production occurred 108 days after the feeding process, and a minimum production was noted and considered irrelevant, so the total cycle of biogas production with peanut shells is comprised in a period of 108 days. Figure 5 presents the behavior of biogas production.

\section{Table 5 - Biogas production parameters}

\begin{tabular}{|c|c|}
\hline Units / Parameters & Values \\
\hline Peanut shells quantity (liters) & 72 \\
\hline Peanut shells quantity (kilos) & 11.4 \\
\hline Water (liters) & 216 \\
\hline Conditioning time (days) & 108 \\
\hline Biogas production $\left(\mathrm{m}^{3}\right)$ & 0.2 \\
\hline Biofertilizer outlet temperature $\left({ }^{\circ} \mathrm{C}\right)$ & 21 \\
\hline ph & 6.4 \\
\hline Odor & Yes \\
\hline Color & Light brown \\
\hline
\end{tabular}

In order to carry out the economic analysis calculations of energy generated by biogas production, the final residue from peanut production is equivalent to approximately $1,275 \mathrm{~kg} \cdot \mathrm{ha}^{-1}$. The amount of electricity consumption of BRL 0.57202 was also used for each $1 \mathrm{kWh}$ employed by CPFL Energia, a non-stateowned Brazilian group of electric energy generation and distribution (CPFL, 2019). Table 6 presents a series of comparisons for producing biogas, taking into account the production per hectare.

As to the production of Herculândia City, if all this residue were used for producing biogas, 85,000 cylinders and 121,380 Kwh would be produced from each harvest.

Regarding biogas production on small farms, the reduction of electricity consumption can be equivalent to BRL 16.16 saved per hectare in the harvest, in the conditions shown in Table 7.

When compared to studies that estimate the production of biogas from swine residue (Souza et al., 2004; Martins and Oliveira, 2011) and cattle residue (Coldebella, 2006), it is evident that the amount of biogas generated exclusively from peanut shells is much less than that from animal residue. However, based on the results presented, these data are close to those generated from acerola cherry pulp, which has a volume of $0.1 \mathrm{~m}^{3}$ produced from $52.10 \mathrm{~kg}$ of pulp (Bonfim et al., 2019).

Vintila et al. (2019) point out that, in Cameroon, Africa, after processing avocado, cocoa, and peanut crops, a large amount of residue is produced, which, when subjected to experiments, are transformed in gaseous (biogas) and liquid (ethanol) biofuels. The authors also estimate that if peanut skins are used to produce biogas, a volume of $30,376.960 \mathrm{~m}^{3}$ would be produced from the residue generated in the country.

Peanut shells are an abundant and efficient resource for the biotechnological production of renewable fuels. Dahunsi et al. (2017) performed a previous treatment of the residue using the combination of mechanical and thermo alkaline procedures to optimize the retention time by increasing the temperature and pressure on the mixture. At the end of the process, a yield of $1739.20 \mathrm{~m}^{3} / \mathrm{kg}$ was obtained. For Liu et al. (2014), other applications can be developed with peanut shells. The authors used a mixture of 1,800 grams of fish remains from the local industry and available in large quantities, with $200 \mathrm{~g}$ of peanut shells, and produced an amount of $33.99 \mathrm{~L}$ in 20 days of biodigestion.

Further evidence suggests that animal residue can increase the biogas generating capacity of peanut shells, as suggested by Junqueira et al. (2011) and Paes et al. (2016). Thus, an amount of animal residue can be added next to the barrel, if available on the property, with the aim of increasing the biogas generating capacity. Family farming is characterized by the diversification of agricultural activities, which may favor the use of more than one residue to produce biogas. 


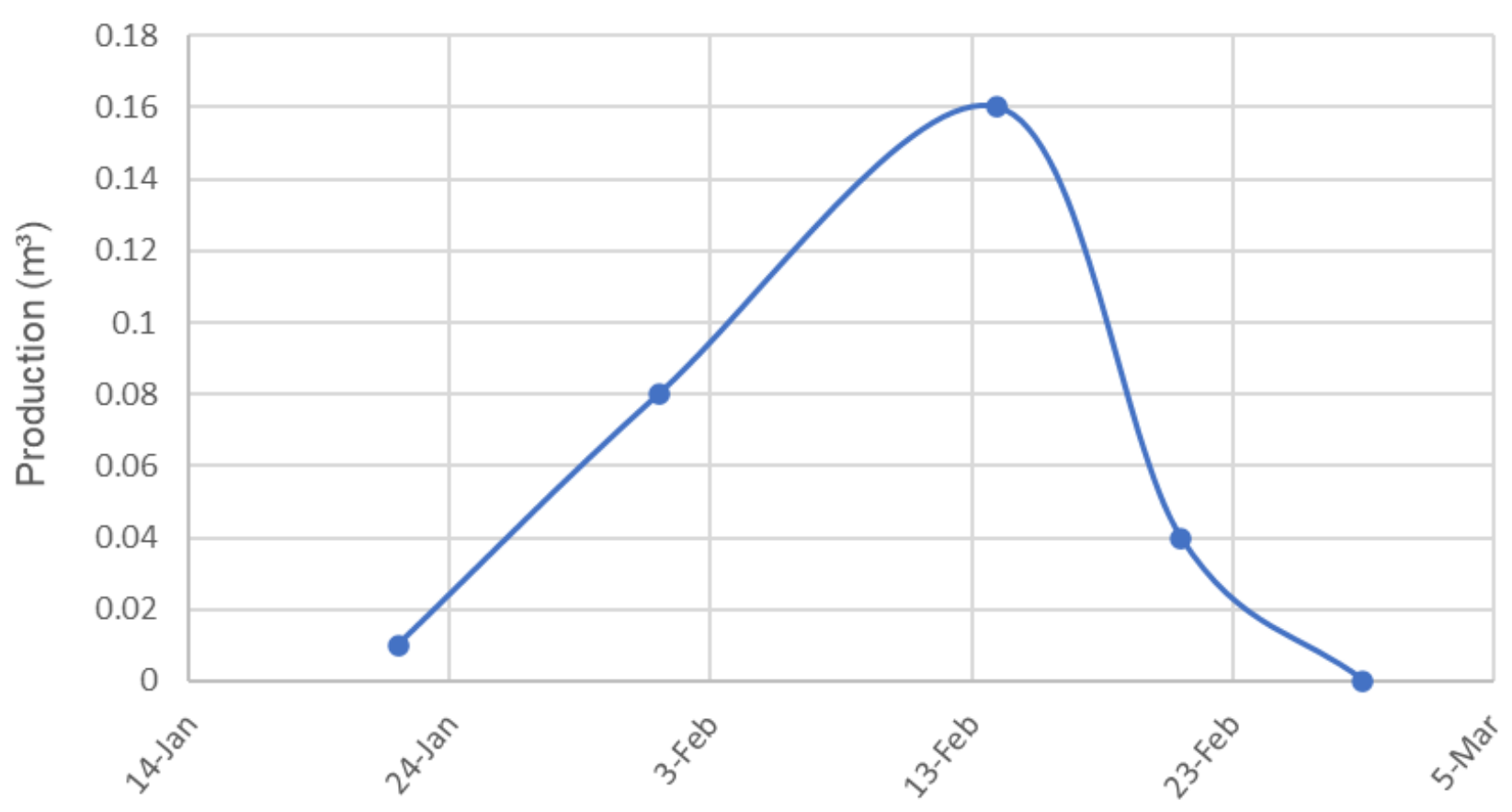

Figure 5 - Monitoring of biogas production

Table 6 - Comparison of residue production with energy resources

\begin{tabular}{|l|c|c|c|}
\hline & Quantity (tonnes) & Biogas m & Kwh/month \\
\hline Residue per hectare & 1.275 & 22.3 & Number of cylinders \\
\hline Residue in Herculândia City & $4,845.0$ & 85,000 & 4 \\
\hline Residue in São Paulo State & $168,858,450.0$ & $14,812,145$ & 15,740 \\
\hline
\end{tabular}

Source: Prepared by the authors, based on the data from the experiment; IBGE (2018); CPFL (2019).

\begin{tabular}{|l|c|c}
\hline Residue $\boldsymbol{b}$ hectare & $1,250 \mathrm{~kg}$ & $22.3 \mathrm{~m}^{3}$ \\
\hline Biogas equivalence & $1 \mathrm{~m}^{3}$ & $1.428 \mathrm{~kW} / \mathrm{h}$ \\
\hline Energy equivalence (hectare per harvest) & $130 \mathrm{days}$ & $31.84 \mathrm{~kW} / \mathrm{h}$ \\
\hline Price of kWh (CPFL, 2019) & $1 \mathrm{~kW} / \mathrm{h}$ & 0.50742 \\
\hline Savings per hectare in the harvest & & BRL 16.16
\end{tabular}

Source: Prepared by the authors, based on the data from the experiment; IBGE (2018); CPFL (2019).

\section{Conclusion}

The use of biodigesters to produce clean energy is in line with the SDGs, which seek to substantially increase the share of renewable energy in the global energy matrix to achieve sustainability. According to the analysis obtained in this work, peanut shells presented a production of approximately $0.2 \mathrm{~m}^{3}$ of biogas in a mixture of $11.4 \mathrm{~kg}$ of ground peanut shells with 216 liters of water. Regarding production per hectare, residues have the potential to generate an amount of $22.3 \mathrm{~m}^{3}$ of biogas, which corresponds to a generated energy of 31.84 Kwh per month.

Even though peanut shells present low potential in the generation of biogas when compared to animal residue, they have the potential to be used in small rural properties, since the energy consumption of family farms tends to be low. However, the use of peanut shells to produce biogas conveys the generation of electric energy from renewable sources in a decentralized manner, minimizing the use of energy from the concessionaires. 


\section{Contribution of authors:}

Santos, C.: Conceptualization, Data curation, Formal analysis, Investigation, Methodology, Writing - original draft. Lourenzani, A.: Supervision, Validation, Visualization, Writing - review \& editing. Mollo, M.: Supervision, Validation, Visualization, Writing - review \& editing. Lopes, A.: Data curation, Formal analysis, Investigation, Project administration, Resources. Santos, P.: Methodology, Project administration, Resources, Supervision, Writing - review \& editing.

\section{References}

Almeida, C., 2016. Potencial de produção de biogás a partir de biomassa de suinocultura com culturas energéticas. Dissertation, Programa de PósGraduação em Engenharia de Energia na Agricultura, Universidade Estadual do Oeste do Paraná, Cascavel.

Almeida, R.G., 2012. Estudo da Geração de resíduos sólidos domiciliares urbanos do município de Caçador SC, a partir da caracterização física e composição gravimétrica. Ignis: Periódico Científico de Arquitetura e Urbanismo, Engenharias e Tecnologia da Informação, v. 1, (1), 51-70.

Araújo, W.D.; Goneli, A.L.D.; Souza, C.M.A.; Gonçalves, A.A.; Vilhasanti, H.C.B., 2014. Propriedades físicas dos grãos de amendoim durante a secagem. Revista Brasileira de Engenharia Agrícola e Ambiental, v. 18, (3), 279-286. https://doi.org/10.1590/S1415-43662014000300006.

Awasthi, S.K.; Joshi, R.; Dhar, H.; Verma, S.; Awasthi, M.K.; Varjani, S.; Sarsaiya, S.; Zhang, Z.; Kumar, S., 2018. Improving methane yield and quality via co-digestion of cow dung mixed with food waste. Bioresource Technology, v. 251, 259-263. https://doi.org/10.1016/j.biortech.2017.12.063.

Azevedo, C., 2014. Regulação e Gestão de Resíduos Sólidos em Portos Marítimos: Análise e Proposições para o Brasil. Thesis, Universidade Federal do Rio de Janeiro, Rio de Janeiro.

Aziz, N.I.H.A.; Hanafiah, M.M., 2020. Life cycle analysis of biogas production from anaerobic digestion of palm oil mill efluente. Renewable Energy, v. 145, 847-857.

Baldacin, A.C.S.; Pinto, G.M.F., 2015. Biodigestão anaeróbia da vinhaça: aproveitamento energético do biogás. Revista Eletrônica FACP, (7), 1-47.

Barbieri, J.C.; Vasconcelos, I.F.G.; Andreassi, T.; Vasconcelos, F.C., 2010. Inovação e sustentabilidade: novos modelos e proposições. Revista de Administração de Empresas, v. 50, (2), 146-154. https://doi.org/10.1590/S003475902010000200002 .

Bezerra, K.L.P.; Ferreira, A.H.C.; Cardoso, E.S.; Monteiro, J.M.; Amorim, I.S.; Santana Júnior, H.A.; Silva, R.N., 2014. Uso de biodigestores na suinocultura. Nutritime, v. 11, (5), 3714-3722.

Biasi, C.A.F.; Mariani, L.F.; Picinatto, A.G.; Zank, J.C.C., 2018. Energias renováveis na área rural da Região Sul do Brasil. Itaipu Binacional, Foz do Iguaçu, 202 pp.

Bilotta, P.; Ross, B.Z., 2016. Estimativa de geração de energia e emissão evitada de gás de efeito estufa na recuperação de biogás produzido em estação de tratamento de esgotos. Engenharia Sanitária e Ambiental, v. 21, (2), 275-282. https://doi.org/10.1590/s1413-41522016141477.

Bonfim, O.E.T.; Reis, A.L.; Santos, C.V.; Soares, W.C.; Oliveira, V.A.B., 2019. Estimativa do Potencial de Geração de Biogás Oriundos de Resíduo de Polpa de Maracujá e Acerola. Revista Brasileira de Energias Renováveis, v. 8, (1), 316325. http://dx.doi.org/10.5380/rber.v8i1.56887.

Brancoli, P.L., 2014. Avaliação experimental da co-digestão anaeróbia de resíduos orgânicos e lodo de esgoto em digestores têxteis. Monograph, Escola Politécnica, Universidade Federal do Rio de Janeiro, Rio de Janeiro.
Brasil. 2018. Ministério de Minas e Energia. Empresa de Pesquisa Energética. Plano Decenal de Expansão de Energia 2027. Ministério de Minas e Energia. Empresa de Pesquisa Energética, Brasília.

Campos, V.B.; Cavalcante, L.F.; Campos, S.S.P.; Gheyi, H.R.; Chaves, L.H.G.; Mesquita, F.O., 2011. Esterco bovino líquido em luvissolo sódico: Resposta biométrica e produtiva do maracujazeiro amarelo. Idesia, v. 29, (2), 59-67. https://doi.org/10.4067/S0718-34292011000200008.

Centro de Estudos Avançados em Economia Aplicada da Escola Superior de Agricultura "Luiz de Queiroz" (CEPEA/ESALQ); Confederação da Agricultura e Pecuária do Brasil (CNA). 2020. PIB do Agronegócio (Accessed April 8, 2020) at: https://www.cepea.esalq.usp.br/br/pib-doagronegocio-brasileiro.aspx.

Chizzotti, M.L.; Pereira, L.G.R.; Chizzotti, F.H.M.; Ladeira, M.M.; Machado Neto, O.R., 2012. Uso da nutrição para redução na geração de metano: Eficiência no uso da energia para ruminantes $\mathrm{x}$ meio ambiente. In: II Simpósio Brasileiro de Produção de Ruminantes no Cerrado. Anais... Universidade Federal de Uberlândia, Uberlândia.

Coldebella, A., 2006. Viabilidade do uso do biogás da bovinocultura e suinocultura para geração de energia elétrica e irrigação em propriedades rurais. Dissertation, Universidade Estadual do Oeste do Paraná, Cascavel.

Companhia Paulista de Força e Luz (CPFL), 2019. (Accessed on April 10, 2020) at: https://www.cpfl.com.br/atendimento-a-consumidores/cpfl-paulista/ Paginas/default.aspx.

Correa, B.A.; Parreira, M.C.; Martins, J.S.; Ribeiro, R.C.; Silva, E.M., 2019. Reaproveitamento de resíduos orgânicos regionais agroindustriais da Amazônia Tocantina como substratos alternativos na produção de mudas de alface. Revista Brasileira de Agropecuária Sustentável, v. 9, (1), 97-104. https:// doi.org/10.21206/rbas.v9i1.7970.

Dahunsi, S.O.; Oranusi, S.; Efeovbokhan, V.E., 2017. Optimization of pretreatment, process performance, mass and energy balance in the anaerobic digestion of Arachis hypogaea (Peanut) hull. Energy Conversion and Management, 139, 260-275. https://doi.org/10.1016/j.enconman.2017.02.063.

Feil, A.; Spilki, F.; Schreiber, D., 2015. Análise global das características de frações de resíduos urbanos residenciais. Revista Brasileira de Ciências Ambientais (Online), (38), 63-77. https://doi.org/10.5327/Z2176-9478201510914.

Galbiatti, J.A.; Caramelo, A.D.; Chiconato, D.A.; Araújo, J.R.; Girardi, E.A., 2011. Quali/quantitative characterization of biogas produced in batch digesters supplied with six distinct substrates. Engenharia Agrícola, v. 31, (4), 795-802. https://doi.org/10.1590/S0100-69162011000400017.

Gonçalves, M.M.; Schledck, G.; Schwengber, J.E., 2009. Produção e uso de biofertilizantes em sistemas de produção de base ecológica. Embrapa Clima Temperado, Pelotas.

Instituto Brasileiro de Geografia e Estatística (IBGE). 2017. Produção Agrícola - Lavoura Temporária (Accessed on April 10, 2020) at: https://cidades.ibge.gov. $\mathrm{br} / \mathrm{brasil} / \mathrm{sp} /$ herculandia/pesquisa/14/10193. 
Instituto Brasileiro de Geografia e Estatística (IBGE). 2018. Produção Agrícola 2017. (Accessed on January 2, 2019) at: https://cidades.ibge.gov.br/brasil/ pesquisa $/ 14 / 10193$ ?localidade $1=35 \&$ localidade $2=3$.

Junqueira, J.B.; Lucas Jr., J.; Costa, L.V.C.; Sagula, A.; Meneses, S.L., 2011. Diluição e separação das frações sólida e líquida de dejetos de bovinos de corte para abastecimento de biodigestores anaeróbios. In: Simpósio Internacional sobre Gerenciamento de Resíduos Agropecuários e Agroindustriais, 2., 2011, Foz do Iguaçu. Anais eletrônicos... SBERA, Foz do Iguaçu.

Kunz, A.; Steinmetz, R.L.R.; Amaral, A.C., 2019. Fundamentos da digestão anaeróbia, purificação do biogás, uso e tratamento do digestato. Embrapa Suínos e Aves.

Liu, A.; Xu, S.; Lu, C.; Peng, P.; Zhang, Y.; Feng, D.; Liu, Y., 2014. Anaerobic fermentation by aquatic product wastes and other auxiliary materials. Clean Technologies and Environmental Policy, v. 16, 415-421. https://doi. org/10.1007/s10098-013-0640-4.

Lora, E.S.; Andrade, R.V., 2009. Biomass as energy source in Brazil. Renewable and Sustainable Energy Reviews, v. 13, (4), 777-788. https://doi.org/10.1016/j.rser.2007.12.004.

Martins, F.M.; Oliveira, P.A.V., 2011. Análise econômica da geração de energia elétrica a partir do biogás na suinocultura. Embrapa Suínos e Aves.

Masson, I.S.; Costa, G.H.G.; Rovievo, J.P.; Freita, L.A.; Mutton, M.A.; Mutton, M.J.R., 2015. Produção de bioetanol a partir da fermentação de caldo de sorgo sacarino e cana-de-açúcar. Ciência Rural, v. 45, (9), 1695-1700. http://dx.doi. org/10.1590/0103-8478cr20130549.

Milhomem Filho, E.O.; Oliveira, C.S.B.; Silveira, L.C.L.; Cruz, T.M.; Souza, G.S.; Costa Júnior, J.M.F.; Pinheiro, M.C.N., 2016. A ingestão de pescado e as concentrações de mercúrio em famílias de pescadores de Imperatriz (MA). Revista Brasileira de Epidemiologia, v. 19, (1), 14-25. https://doi. org/10.1590/1980-5497201600010002.

Miyagawa, L.J.P.P.; Mendes, T.A.A.; Marmos, J.L., 2016. Caracterização da contaminação por chorume nos recursos hídricos superficiais no entorno do aterro de resíduos sólidos de Manaus/AM. Revista Geonorte, v. 7, (27), 30-42.

Mota, F.; Monteiro, L.; Silva, W.; Borges, D., 2019. Climatic characteristics and hourly variations in biogas concentration in a sanitary landfill in Northeast Brazil. Revista Brasileira de Ciências Ambientais (Online), (54), 1-12. https:// doi.org/10.5327/Z2176-94782190077.

Oliveira Filho, F.S.; Cassimiro, C.A.L.; Sousa, P.S.; Alencar, L.V.C.; Feitosa, S.S.; Silva, E.A., 2020. Biofertilizante como solução nutritiva para produção de alface hidropônica no Alto Sertão paraibano. Revista Verde de Agroecologia e Desenvolvimento Sustentável, v. 15, (1), 111-117. https://doi.org/10.18378/ rvads.v15i1.6440.

Oliveira, J.V.; Alves, M.M.; Costa, J.C., 2018. Biochemical methane potential of brewery by-products. Clean Technologies and Environmental Policy, v. 20, (2), 435-440. https://doi.org/10.1007/s10098-017-1482-2.
Organização das Nações Unidas (ONU). 2015. Cúpula das Nações Unidas sobre o Desenvolvimento Sustentável (Accessed April 10, 2020) at: https:// nacoesunidas.org/pos2015/agenda2030/.

Paes, L.; Kalb, S.; Lombardo, R.; Farias, M.; Souza, P.; Rovena, L.; Schwarz, K., 2016. Avaliação do uso de resíduo de curtume de couro de peixe como alternativa na recuperação biológica de solos degradados. Revista Brasileira de Ciências Ambientais (Online), (40), 69-79. https://doi.org/10.5327/Z2176947820162014

Pelissari, P.G.Z.; Paz, D.; Boron L.; Hermes, E.; Mucelim, E.C., 2010. Utilização de resíduo de fécula de mandioca como agregado de argamassa de revestimento. Engenharia Ambiental, v. 7, (1), 109-120.

Polachini, T.C.; Sato, A.C.K.; Cunha, R.L.; Telis-Romero, J., 2016. Density and rheology of acid suspensions of peanut waste in different conditions: an engineering basis for bioethanol production. Powder Technology, v. 294, 168176. http://dx.doi.org/10.1016/j.powtec.2016.02.022.

Ryckebosch, E.; Drouillon, M.; Vervaeren, H., 2011. Techniques for transformation of biogas to biomethane. Biomass and Bioenergy, v. 35, (5), 1633-1645. https://doi.org/10.1016/j.biombioe.2011.02.033.

Santos, A.C.V., 1991. Efeitos nutricionais e fitossanitários do biofertilizante líquido a nível de campo. Revista Brasileira de Fruticultura, v.13, (4), 275-279.

Slorach, P.C.; Jeswani, H.K.; Cuéllar-Franca, R.; Azapagic, A., 2019. Environmental sustainability of anaerobic digestion of household food waste. Journal of Environmental Management, v. 236, 798-814. https://doi. org/10.1016/j.jenvman.2019.02.001.

Souza, S.N.M.; Pereira, W.C.; Nogueira, C.E.C.; Pavan, A.A.; Sordi, A., 2004. Custo da eletricidade gerada em conjunto motor gerador utilizando biogás da suinocultura. Acta Scientiarum Technology, v. 26, (2), 127-133. https://doi. org/10.4025/actascitechnol.v26i2.1510.

Verri, R.; Ribeiro, R.; Gasparotto, F., 2017. Setor sucroenergético: uma análise sob o tripé da sustentabilidade. Revista Brasileira de Ciências Ambientais (Online), (45), 33-47. https://doi.org/10.5327/Z2176-947820170228.

Vintila, T.; Ionel, I.; Tagne Tiegam, R.F.; Wächter, A.R.; Julean, C.; Gabche, A.S., 2019. Residual biomass from food processing industry in Cameroon as feedstock for second-generation biofuels. BioResources, v. 14, (2), 37313745 .

Zanoni, M.V.; Zanatta, J.A.; Dieckow, J.; Kan, A.; Reissmann, C.B., 2015. Emissão de metano por decomposição de resíduo florestal inundado. Revista Brasileira de Engenharia Agrícola e Ambiental, v. 19, (2), 173-179. https://doi. org/10.1590/1807-1929/agriambi.v19n2p173-179.

Zhao, X.; Chen, J; Du, F., 2012. Potential use of peanut by-products in food processing: a review. Journal of Food Science and Technology, v. 49, (5), 521529. https://dx.doi.org/10.1007\%2Fs13197-011-0449-2. 